\section{CONCERTED BEHAVIOR OF TERRESTRIAL MOLLUSKS}

ON August 29, 1915, the writer collected 125 specimens of Cochlicopa lubrica (lot 146a) from the outer surface of the door and frame of the "dark room" at the Iowa Lakeside Laboratory, on Lake Okoboji. This small frame building is more than half imbedded in the hillside about 15 feet above the level of the lake. The roof is covered with humus dirt and vegetation. A short passageway walled with heavy boards leads to the doorway.

Throughout the preceding night there had been a constant, cold rain. On the morning of the 29th there was a cold, drying wind. On the afternoon of this day I chanced to notice a specimen of Cochliciopa on the door-frame; closer examination then revealed a good many, and I spent an hour or more in gathering them. Those attached to the walls were at all heights, with the apex directly downwards, which latter fact, I presume, indicates that their movement had been upwards. None of the specimens were moving at the time, but all were retracted and fastened by a secretion to the substrate. Doubtless this condition is explained by the fact that the wind had made the planks so dry that locomotion was difficult or impossible. Ten or fifteen specimens were picked up from the ground close to the wall, but were inactive and lay as they had fallen. A few, also, were found in cobwebs, by which they had been caught as they fell from the vertical walls. While a few specimens were found on the south wall, most were on the north wall (which faced the south) and the northeast corner of the building (which faced east to north). Besides the Cochlicoper, a considerable number of specimens of Vallonia gracilicosta were found; and also about fifteen specimens of Bifidaria armifera. However, the two latter species did not exhibit any uniformity in orientation, so far as noticed, at least.

Concerning the Cochlicopo, the writer was puzzled to account, not only for their presence in rather large numbers, but for the singular uniformity of their behavior. The snails on the vertical walls were at all heights from the ground, and all exhibited precisely the same orientation, viz., the apex of the shell pointed downward. They evidently had come from the ground below. But why should they be moving upward? Under conditions of drouth and cold one would expect these forms to exhibit a positively geotropic response. Close to the water's edge among the rocks and fallen leaves the writer had been accustomed to find this species rather common; but never so many in a given area as occurred on this occasion. None had ever been found on this slope so far up, before.

It seemed to the writer that so many of these snails being found together, and with similar orientation, was a fact inviting explanation, which, however, he is unable to furnish. This case differs from the synchronic behavior recently described in Science by several authors, in that it lacks the element of rhythm. In the movement of the group of harvestmen, as described by Newman, and the simultaneous movement of the fall web-worn, described by Peairs, there is a rhythmic group movement which may be distinguished from concert of action. And while I am unable to explain the behavior of these snails, I am inclined to look upon it as a sort of concerted action.

\section{Morningside College, Sloux Citr, IA.}

\section{T. C. Stephens}

\section{A COUNTRY WITHOUT A NAME}

To the Editor of Science: I am glad to see that some one has at last had the insight and courage to note and call attention to the fact that our nation has no name. "The United States" is no name at all, and merely because we call the United States of Mexico "Mexico," and the United States of Brazil "Brazil," is no justification for calling the United States of America "America." Our brothers to our north call us "the States," which is about as meaningless as anything can be, but it is our own fault that we are so called. Some years ago there was a popular musical comedy containing a song entitled "My own United States," but it could arouse no thrill with such a handicap. Indeed we do need a national name more than a national flower, 
though I do not know what we can do now to correct our faulty condition, one hundred and forty years after the birth of our nameless nation. Would that our fathers had seized upon our beautiful nickname, "Columbia," for our own official designation, before our pugnacious southern neighbor Columbia had stolen it for herself!

\section{WESTERN RESERVE UNIVERSITY, Clevterand, Ohio}

J. S. Moore

To the Editor of ScIence: The name "America" inspires millions of individuals and the logical necessity for a name which is more specific, as pointed out by one of your correspondents in ScIENCE of July 5, will gain little acknowledgment and no popularity. Nevertheless the necessity remains and should be dealt with. The custom and sentiment of the masses is the deciding factor and any change can come only by a gradual transformation. If the term America, like Europe, Africa and Asia applies to a continent, as it does, then American implies Canadian, Brazilian and Patagonian just as well. We have in our case the modifying factor of "United States," which, as the correspondent puts it: "is lacking an adjective." To supply this adjective another name is needed. Why not hit two marks in one stroke by printing upon our postage stamps: USoNA? Perhaps this name might gain popularity and would permit an adjective "Usonian." At the same time the most numerous representatives of the nation would sail under a more specific label: U. S. o. N. A. instead of U. S. POSTAGE. Incidentally I wonder how long the inaccurate use of U. S. A. will survive. It has often been pointed out that U. S. A. is the official abbreviation for "United States Army" and U. S. N. for the navy, while U. S. means the United States and U. S. N. A. the United States of North America. Perhaps an experiment with postage stamps, as suggested above, may educate the people to use Usona, or the correct U. S.

\section{Berkelex, Calif.}

\section{SCIENTIFIC BOOKS}

City Milk Supply. By Horatio Newton Parker. New York, McGraw-Hill Book Company, Inc. Pp. 486.

The author's purpose is plainly set forth in the brief preface, namely to give much-needed information on the broad subject of milk production, transportation and control of purity. This purpose he has admirably accomplished. The book seems complete in itself. The subject matter is divided into seven chapters, as follows: I. Milk; II., Diseases Communicable in Milk; III., Dairy Cattle and the Dairy Farm; IV., Sanitary Milk Production; V., Transportation of Milk; VI., The Milk Contractor, and VII., Control of the Public Milk Supply.

Printed in somewhat compact form, in good bold type and on good paper, the different topics are presented clearly, and in many parts with the first-hand information and understanding of the various difficult problems which only one who has spent many years of study in this field is able to give.

In the chapter on diseases communicable in milk the treatment of tuberculosis is particularly instructive. The tuberculin test, and the present-day controversy regarding its value and enforced application are discussed at some length and without bias. Septic sore throat likewise comes in for a good share of the writer's attention.

A comprehensive history of the score card system of rating dairies, and a full discussion of its merits and of its serious limitations will be found to be interesting and illuminating. The importance which the author attaches to the bacteriological examination of milk is most gratifying to those who have long lent their support to its complete adoption as a method of controlling sanitary milk production. A good account is given also of the origin and pernicious influence of the so-called "slop dairy," and of the long struggle that has been waged for improved feeding and housing conditions in the dairy barn.

The author has been particularly successful in his treatment of the material in the chapter on the milk contractor. The peculiar 